Review

\title{
Porphyrins as Theranostic Agents from Prehistoric to Modern Times
}

\author{
Yumiao Zhang ${ }^{1}$, Jonathan F. Lovell1,2凶 \\ 1. Department of Chemical and Biological Engineering; \\ 2. Department of Biomedical Engineering, University at Buffalo, State University of New York, Buffalo, New York 14260, \\ United States
}

$\triangle$ Corresponding author: Email: jflovell@buffalo.edu

(C) Ivyspring International Publisher. This is an open-access article distributed under the terms of the Creative Commons License (http://creativecommons.org/ licenses/by-nc-nd/3.0/). Reproduction is permitted for personal, noncommercial use, provided that the article is in whole, unmodified, and properly cited.

Received: 2012.07.20; Accepted: 2012.08.17; Published: 2012.09.30

\begin{abstract}
Long before humans roamed the planet, porphyrins in blood were serving not only as indispensable oxygen carriers, but also as the bright red contrast agent that unmistakably indicates injury sites. They have proven valuable as whole body imaging modalities have emerged, with endogenous hemoglobin porphyrins being used for new approaches such as functional magnetic resonance imaging and photoacoustic imaging. With the capability for both near infrared fluorescence imaging and phototherapy, porphyrins were the first exogenous agents that were employed with intrinsic multimodal theranostic character. Porphyrins have been used as tumor-specific diagnostic fluorescence imaging agents since 1924, as positron emission agents since 195I, and as magnetic resonance (MR) contrast agents since 1987. Exogenous porphyrins remain in clinical use for photodynamic therapy. Because they can chelate a wide range of metals, exogenous porphyrins have demonstrated potential for use in radiotherapy and multimodal imaging modalities. Going forward, intrinsic porphyrin biocompatibility and multimodality will keep new applications of this class of molecules at the forefront of theranostic research.
\end{abstract}

Key words: Porphyrins, theranostics

\section{Hundreds of millions of years of theranostics}

Porphyrins exist abundantly in plants, animals and rocks [1] and have even been found in lunar dust [2]. They existed by the time the first chlorophyll-containing photosynthetic organisms appeared some 3 billion years ago to initiate the creation of a new atmosphere, rich with life-supporting oxygen [3]. Our present ecosystem relies extensively on porphyrins for various vital roles ranging from photosynthesis to oxygen transport, in the form of chlorophyll and heme. Iron, which is chelated in the center of the heme group, may have been selected instead of another metal for evolutionary reasons, due to its abundance in the crust of earth [4]. Hemoglobin and myoglobin are believed to have emerged more than 600 million years ago [5]. Structurally, hemoglobin consists of four protein subunits, with each subunit associated with a heme group chelated with an iron atom in the center (Fig 1a) [6]. Its evolution permitted animals to develop complex circulatory systems, which in turn permitted larger organism sizes and higher functions. Hemoglobin is packed into red blood cells (RBCs), which are the most abundant cells in blood and can be traced back to ancient times (for e.g., a probable 65 million year old dinosaur RBC is shown in Fig. 1b) [7]. RBCs have a characteristic biconcave shape $7-8 \mu \mathrm{m}$ in diameter and play a major role in human physiology 
[8]. RBCs are produced at an astounding rate of approximately $2 \times 10^{6}$ per second and there are $2-3 \times 10^{13}$ in circulation at any given moment in a human adult body. Oxygen delivery is mediated by the nearly 300 million hemoglobin molecules in each RBC, which comprise some $3 \times 10^{22}$ total heme porphyrin group in the body [9] (Fig 1a). In addition, a wide range of other porphyrins is found in prosthetic groups within cells (e.g. cytochromes and vitamin B12).
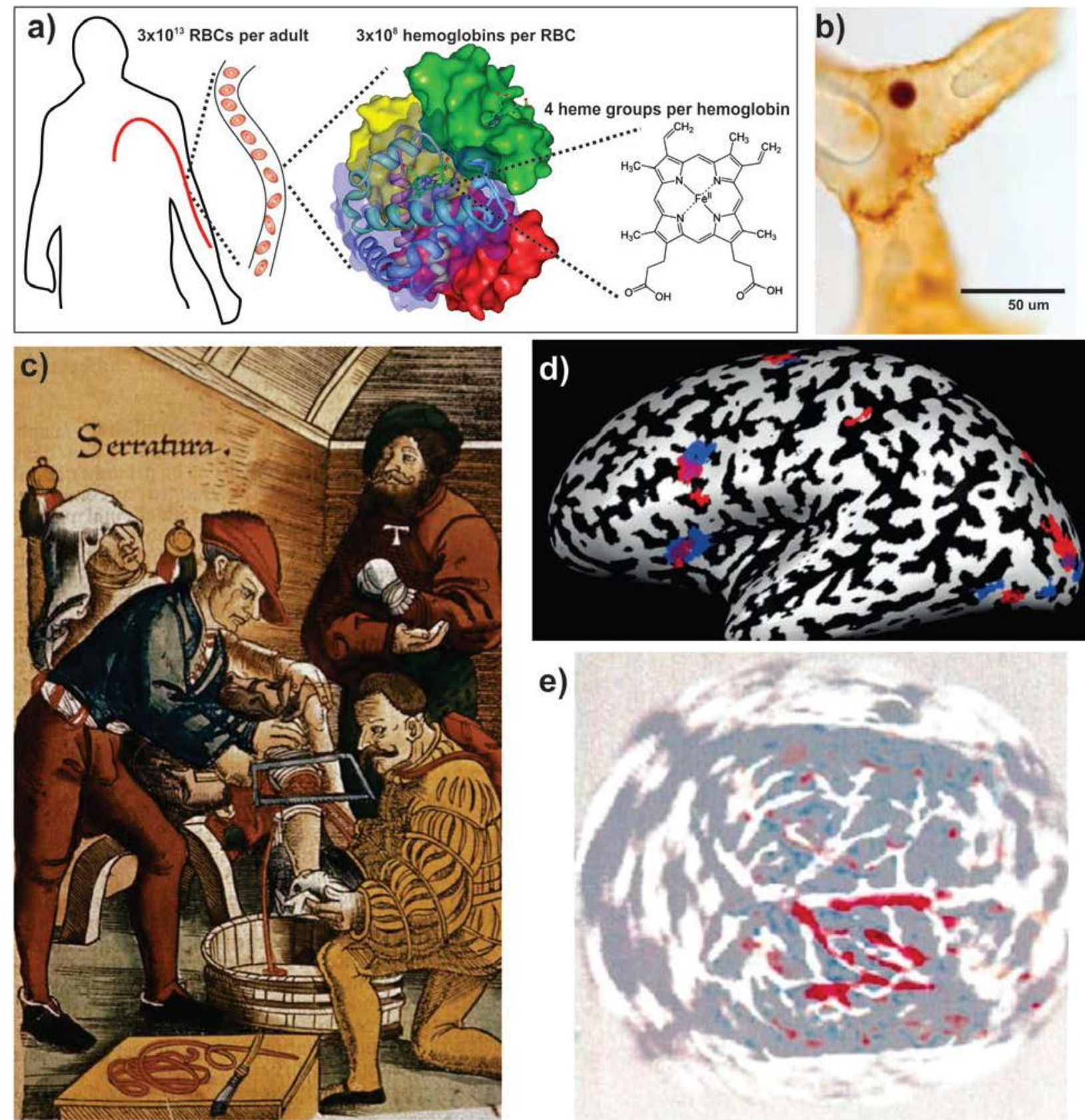

e)

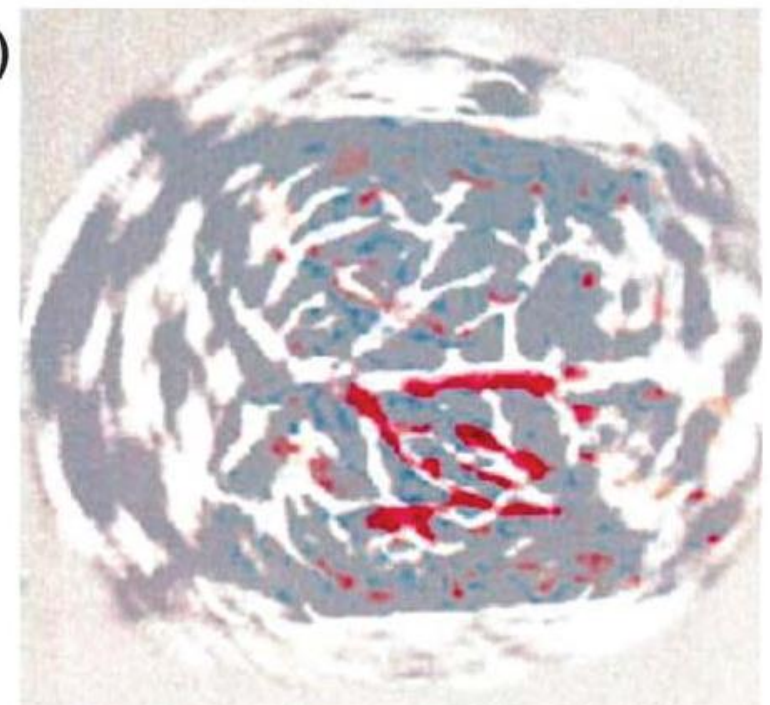

Figure I: Endogenous porphyrins. a) Schematic organization of heme in the body [6,9]. b) A possible heme-containing red blood cell identified in 65 million year old dinosaur tissue [7]. c) Surgical illustration of an amputation from circa I500 AD. Excessive bleeding can readily be observed due to the bright red heme to guide tourniquet application (Archives \& Special Collections, Columbia University Health Sciences Library). d) BOLD MR imaging using heme oxygenation. In this case neural differences between English and Hebrew speech patterns are shown. Blue and red regions are involved in morphological processing in Hebrew and English, respectively and regions of overlap are shown in purple [22]. e) Non-invasive, rat brain transcranial photoacoustic imaging following right-side whisker stimulation [26]. Reproduced with permission from the publishers of corresponding references. 
Hemoglobin was first isolated by Hunefeld in $1840[5,10]$ and its molecular structure was revealed over one hundred years later using X-ray crystallography [11]. The first analytical applications using porphyrins originate much earlier, in the era of the first blood-bearing creatures. Heme has long been recognized as the red pigment of our blood, even if the molecular details were not known. Porphyrins in different forms can be found in many different colors. Among them, the bright red color of blood, visible under natural light, has been providing health guidance for millions of years already. For instance, an injury that causes bleeding can be detected by eye by both an injured animal and other parties who wish to provide assistance (or possibly prey on the injured). Fig $1 \mathrm{c}$ shows a $16^{\text {th }}$ century painting of an amputation operation from one of the earliest recorded medical textbooks, illustrating how visual detection of blood has long provided optical feedback for guiding medical procedures. The evolutionary importance of heme is reflected in human responses to even the sight of the color red. Immersion in red rooms is associated with generating active and excited psychological states and it has been shown that some muscular responses are over 10 percent faster than normal in red light [12]. Red stimulates tension and restlessness; physiologically, the sight of the color can even increase blood pressure, pulse and respiration [13]. Thus, the intrinsic importance of heme as an indicator for bleeding is reflected in its role through human evolution to invoke response and reaction to avoid and deal with bleeding. Today, blood still maintains its theranostic legacy in millions of medical procedures performed each day as an endogenous and highly visible optical contrast agent.

In the past decades, technological advances in medical imaging have emerged concurrently and co-operatively with theranostic medicine [14]. Heme serves as an important endogenous contrast agent in at least two imaging techniques; functional magnetic resonance imaging (fMRI), and photoacoustic tomography (PAT). Hemoglobin in the form of oxyhemoglobin carries molecular oxygen to cells for cellular respiration and following oxygen delivery, returns to the lungs in the form of deoxyhemoglobin. The iron chelated in the center of hemoglobin can change its valency between $\mathrm{Fe}^{2+}$ and $\mathrm{Fe}^{3+}$ to help enable precise oxygen delivery [15]. The differences between oxy and deoxyhemoglobin can be detected by optical and MR methods.

Understanding neural activities via functional brain mapping is challenging. Fluctuating electrical signals on the scalp have been able to provide some information about electrical activity in the outer cor- tex of the brain, but cannot provide a deep or detailed three-dimensional volumetric map of brain activity. The birth of fMRI ushered in a new era in the study of the working brain and serves as a central focus in modern neuroimaging since it enables indirect measurement of metabolic activity and blood changes caused by neural activity. fMRI was developed on the basis of nuclear magnetic resonance (NMR) and magnetic resonance imaging (MRI). NMR, discovered in 1946, is based on the phenomenon of nuclear spin, resulting in resonance radiofrequency absorption in the presence of an extrinsic magnetic field [16]. About 30 years later, MRI emerged based on tissue-specific differences in transverse and longitudinal relaxation rates among different tissues [17]. The focus of fMRI, compared to the conventional MRI, is to investigate metabolic activities through its sensitivity to relative levels of oxygen in blood. This technique, which has been gaining much attention since 1991, offers an indirect interpretation of neural activity based on the changes of blood volume, blood flow and blood oxygenation (also collectively referred to as hemodynamic oxygenation) [18-20]. It has been shown that when diamagnetic oxyhemoglobin releases its oxygen, the dexoyhemoglobin becomes paramagnetic, which influences the transverse relaxation rates of water proton spins in the immediate vicinity of vessels, resulting in the blood oxygenation level dependent (BOLD) contrast [21]. When a certain area of brain is active, oxygen metabolic rate increases, but the blood flow increases as well so the overall outcome is the oxygen extraction fraction drops, leading to more oxygenated venous blood, ultimately resulting in locally increasing MR signals. Even when the brain is given only somewhat different tasks, for instance, using either English or Hebrew speech patterns, remarkably precise activation maps of the brain can be obtained by fMRI (Fig. 1d) [22].

PAT is an emerging and high resolution optical imaging technique based on the photoacoustic effect $[23,24]$. When biological tissues absorb a pulse of optical energy, the acoustic transient pressure excited by thermoelastic expansion will produce ultrasonic waves, referred to as photoacoustic waves. These waves are detected by an ultrasonic transducer and converted into electric signals which are used to generate images $[24,25]$. Photoacoustic imaging can be used to non-invasively obtain functional images based on differences in optical absorption between oxy- and deoxy hemoglobin contained in blood. Photoacoustic methods can provide information on hemoglobin concentration and oxygen saturation, indicating tumor angiogenesis, hypoxia or hypermetabolism, which are important parameters of cancer char- 
acterization. Meanwhile, based on the relation of neural activity and cerebral blood parameters (e.g. hemodynamics), PAT of cerebral activity can be obtained noninvasively and infer neural activity. As shown in Fig 1e, PAT can be used for functional imaging of cerebral hemodynamic changes induced by whisker stimulation in a rat [26]. Also, increasing focus has been placed on clinical applications in humans. For example, it was shown that PAT can be used to obtain images of breast tumors [27] and subcutaneous microvasculature skin in humans [28]. There still remains some challenges for applying PAT in the human brain due to the thickness of human skull [29]. As imaging methods improve, fMRI and PAT will continue to be prominent functional imaging modalities based on oxy and deoxy heme.

\section{The original exogenous agents for imag- ing and therapy}

Endogenous porphyrins play a central and historic role in theranostic medicine, but exogenous porphyrins are also of considerable significance. Photodynamic therapy (PDT) is a clinical and minimally invasive method to treat cancers and other diseases. It involves three elements: a photosensitizer, light and oxygen. Porphyrin and porphyrin-related compounds are the most commonly used photosensitizers. After administration and delivery of a photosensitizer to a tumor site and upon light irradiation, it will generate reactive singlet oxygen $\left({ }^{1} \mathrm{O}_{2}\right)$, leading to cell death and tumor destruction [30-35]. Fig. 2a shows the efficacy of PDT using hexyloxyethyl devinylpyropheophorbide-a (HPPH or Photochlor) in destroying esophageal cancer [36]. PDT also has been clinically successful in treating other diseases such as age-related macular degeneration (AMD) and acne [37,38]. Singlet oxygen $\left({ }^{1} \mathrm{O}_{2}\right)$ has a small diffusion range less than the diameter of a cell, therefore restricting damage only to the treatment site [39]. As a variant of PDT, photothermal therapy (PTT) was proposed as another method for cancer treatment using porphyrins at least as early as 1999 [40,41]. Generally, in the promotion of photothermal sensitized processes, photosensitized species can generate electronic excitation energy upon irradiation, leading to local temperature rises and to the destruction of cancer cells [42], even in the absence of oxygen [43]. As shown in Fig $\mathbf{2 b}$, when porphysomes (nanoparticles formed by the conjugation of porphyrin to a phospholipid) were administered to a tumor bearing mouse and irradiated by a $658 \mathrm{~nm}$ laser outputting $750 \mathrm{~mW}$ with a power density of $1.9 \mathrm{~W} / \mathrm{cm}^{2}$ for $1 \mathrm{~min}$, the tumor temperature rapidly increased to $60{ }^{\circ} \mathrm{C}$ while the tumors in control experiment with PBS in- jected did not increase in temperature beyond $40{ }^{\circ} \mathrm{C}$ [44]. Light absorbing species can include metallic nanoparticles (e.g. $\mathrm{Au}, \mathrm{Ag}$ ) [45], cyanine dyes [46], azo-dyes [47], porphyrins [43,48], naphthalocyanines [41] and many others.

In the early 1900s, a number of photosensitizers were investigated for treatments of certain cancers and skin diseases [49-51]. Oscar Raab was perplexed by some inconsistent data that were generated during a heavy lightning storm; he started to wonder about the effect of light and discovered photodynamic reactions in the process [51-53]. Oxygen was soon determined to be an important mediator for photosensitization and the term "photodynamic action" was coined in 1907 [51,54,55]. Hematoporphyrin, usually extracted from bovine blood, has been used since this time. This porphyrin was first isolated from dried blood in 1841 [56,57]; its fluorescence properties were observed in $1867[57,58]$ and its photobiological properties were studied in mice in 1911 [57,59]. When administered hematoporphyrin and irradiated with light, mice exhibited skin photosensitivity and phototoxicity. Around the same time, a German doctor boldly injected hematoporphyrin into himself and demonstrated how exogenous porphyrins were sunlight photosensitizers in humans [51,60]. Another early and important discovery is that the concentration of tetratraphenylporphinesulfonate (TPPS) detected in tumors of rats was higher than that using hematoporphyrins, indicating better tumor localizing ability of TPPS [61]. These pioneering works of PDT occurred mostly in Europe and were reported in non-English languages, but the rich history of PDT has been summarized by several comprehensive literature reviews $[51,57,62]$.

Porphyrins, their derivatives or porphyrin-inducing drugs are by far the most commonly used photosensitizers in PDT. One milestone of PDT occurred when Diamond et al. reported favorable results of cancer treatment in rats in 1972, using crude hematoporphyrins as a photosensitizer combined with white light from fluorescent lamps [63]. When rats bearing subcutaneous glioma cell tumors were intravenously injected with hematoporphyrin and irradiated by white light a day after injection, tumors showed dramatic shrinking. In control experiments, hematoporphyrin or light alone did not have anti-tumor effects. Building on this work, in 1975 Dougherty and coworkers from Roswell Park Cancer Institute in Buffalo demonstrated effective tumor destruction in more advanced animal models [64]. Mice with mammary tumors were administered a hematoporphyrin derivative $(\mathrm{HpD})$ and were exposed to red light. Half the transplanted mouse tumors were 
cured and favorable results were also obtained in the case of the rats bearing chemically-induced tumors given higher doses of $\mathrm{HpD}$. At about the same time, it was found that mice with carcinomas transplanted from human bladder cancers were destroyed using $\mathrm{HpD}$ combined with local exposure to white light [65]. Subsequently, phthalocyanines were introduced as photosensitizers, motivated by their typically higher absorption and longer wavelengths [66]. There have been many porphyrin-related compounds that have had success or show promise for clinical or preclinical applications in PDT. Photofrin, a HpD, has been the most historic and commonly used photosensitizer, approved for the treatment of many cancers including lung, bladder, gastric and cervical. But hematoporphyrin derivatives have two disadvantages: 1) after administration, drugs are retained and taken up by skin so that patients are required to avoid bright light for long time; 2) the limited penetration depth around $630 \mathrm{~nm}$ limits the size of tumors treated effectively $[67,68]$. Therefore, other porphyrin-based photosensitizers have been developed including Verteporfin, Photolon, and others. Other reviews comprehensively describe the clinical state of PDT and clinical trials using photosensitizers [33-35,38,51,69]. Challenges like sunlight toxicity and lack of clinically proven targeting still exist, which have slowed the clinical application of PDT. In the method of vascular photosensitizer targeting, light placement can effectively destroy the vasculature and endothelium around the tumor, which is a promising clinical approach for the treatment of prostate cancer and age-related macular degeneration (AMD) [70,71]. Recently, porphyrins and PDT have been widely employed to treat AMD. This medical condition is caused by choroidal neovascularization $(\mathrm{CNV})$, leading to the damage of retina, loss of vision at macula, even to blindness eventually. Widespread clinical efforts have used verteporfin (trade name Visudyne) with PDT to prevent visual loss [72-75]. PDT using porphyrins has also been applied to treat acne vulgaris, a common disease linked with the bacteria Propionibacterium acnes and the sebaceous glands [76]. Conventionally, antimicrobial and anti-inflammatory drugs and hormones were used topically or orally to fight against the pathogenetic factors [77,78]. PDT has emerged as a highly effective alternative method in skin clinics $[79,80]$. Most acne treatments induce protoporphyrin IX (PpIX) using aminolevulinic acid (ALA) or ALA derivatives and with appropriate light irradiation, PDT can cure inflammatory acne lesions with high efficacy $[81,82]$.

Radiotherapy is another therapeutic modality for cancer treatment that can be mediated by porphyrins.
Generally, aqueous radiolysis can generate free radicals which interact with biomolecules such as DNA, RNA, protein and membrane, resulting in the cell dysfunction and destruction [83]. Due to their preferential uptake in tumors, some porphyrins have been used in targeted tumor radiotherapy when labeled with therapeutic radionuclides [84]. For example, meso-tetrakis [3,4-bis(carboxymethyleneoxy)phenyl] porphyrin $\left(\mathrm{T}_{3,4} \mathrm{CPP}\right)$ was labeled with ${ }^{188} \mathrm{Re}$ and used for targeted radiotherapy in mice [85]. It was shown that in different tumor bearing mice $24 \mathrm{~h}$ postinjection, the tumor/muscle, tumor/blood, and tumor/liver ratio for ${ }^{188} \mathrm{Re}^{-\mathrm{T}_{3,4} \mathrm{CPP}}$ was as high as 19, 9.6 and 4 ,respectively. Fig. 2c shows melanoma imaging of the ${ }^{188}$ Re porphyrin administered in tumor-bearing nude mice, showing the potential for radiotherapy and imaging. A review of ${ }^{111}$ In-tetrphenylporphyrins [86], ${ }^{54} \mathrm{Mn}-\mathrm{HpD}$ [87], ${ }^{109} \mathrm{~Pb}-$ Porphrins [88] and others summarizes radioporphyrin complexes comprehensively [89].

Not only do porphyrins have therapeutic functions, but they also emit fluorescence in the red or near infrared (NIR) and are useful for in vivo imaging. The first observation of porphyrin fluorescence from tumors was reported by Policard in 1924 [57,90]. The red fluorescence from hematoporphyrin was observed in a rat sarcoma during illumination with ultraviolet light but was mistakenly attributed to bacterial infection. Seven years later, similar results in breast carcinomas were observed and the possibility of bacteria was ruled out, confirming porphyrin imaging utility [91]. In 1942, Auler and Banzer studied the localization of exogenously administered hematoporphyrins in tumors and found they favorably accumulated in tumor and lymph nodes in rats [92]. Subsequent studies in the 1940s and 1950s further demonstrated that porphyrins exhibit affinity for neoplastic tissue [93-95]. Thus, well over 50 years prior to the popularization of commercial fluorescence animal imaging systems [96], the fluorescence of porphyrins was observed to differentiate normal tissues and tumors in optical imaging studies. Porphyrin imaging can be used to predict the success or failure of photodynamic treatment $[97,98]$ and also for fluorescence-guided surgical tumor resection [99]. Fluorescence-guided surgery has emerged as an important research area especially for the treatment of the brain tumors. Generally, 5-aminolevulinic acid (5-ALA) is a metabolic precursor inducing the synthesis of PpIX, which leads to the accumulation the fluorescence in malignant glioma tissues, thus providing identification for guided resection of tumors [100-104]. Fig 2d and Fig. 2e show in vivo tumor fluorescence in mice 48 hours post injection of porphysomes [44] and image 
guided resection of brain tumors in rabbit (guided by the fluorescence of PpIX) [105], repectively. Exogenous porphyrins have also been widely used in other optical imaging techniques such as photoacoustic imaging. Fig. $2 \mathrm{f}$ shows the photoacoustic imaging of lymphatic mapping in rats after injection of $2.3 \mathrm{pmol}$ porphysomes.
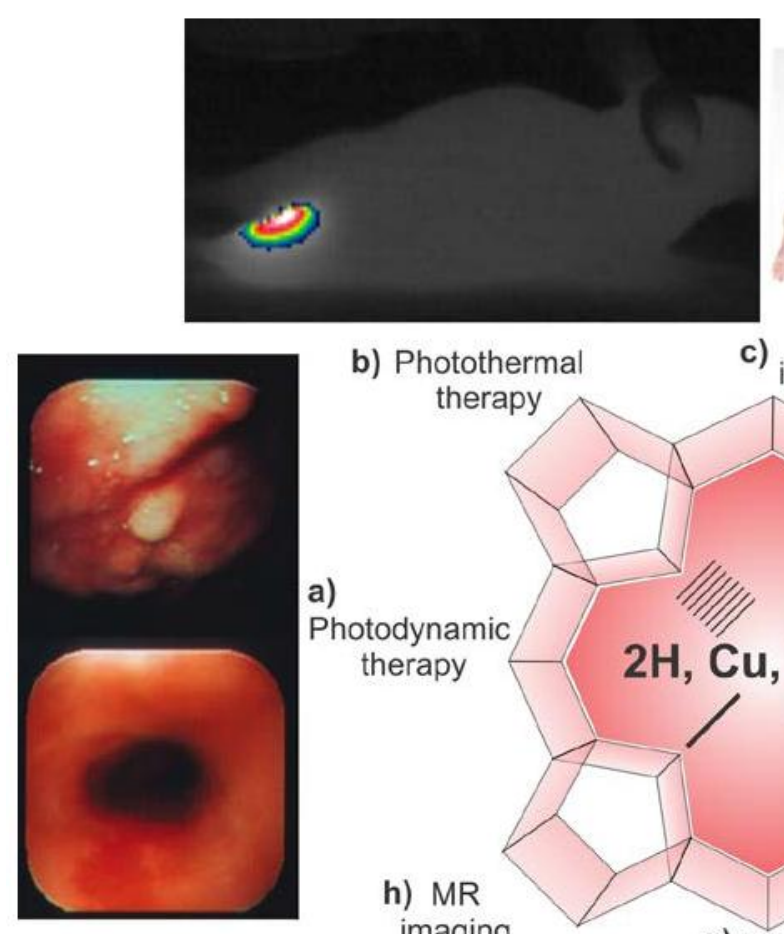

b) Photothermal

therapy

a) Photodynamic therapy

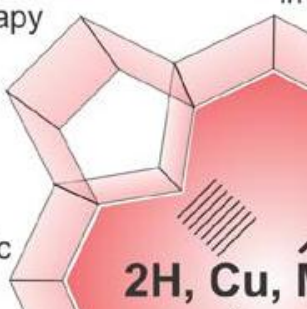

c)

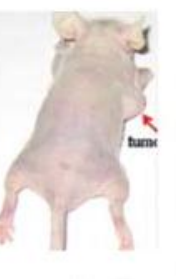

Radio-

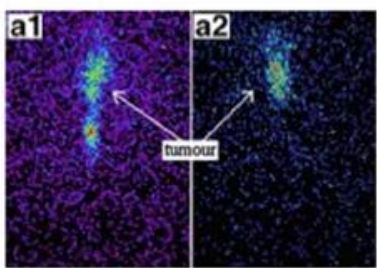

maging/therapy<smiles>CC1CC1[SiH3]</smiles>

d)

Fluorescence Imaging

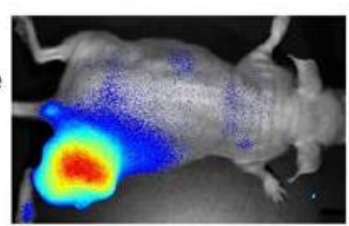

e) Image-guided surgical resection

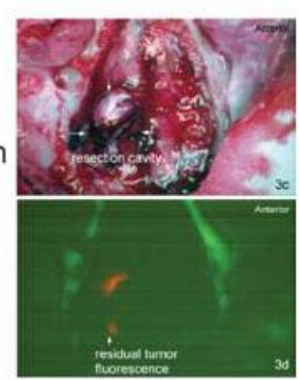

h) MR imaging
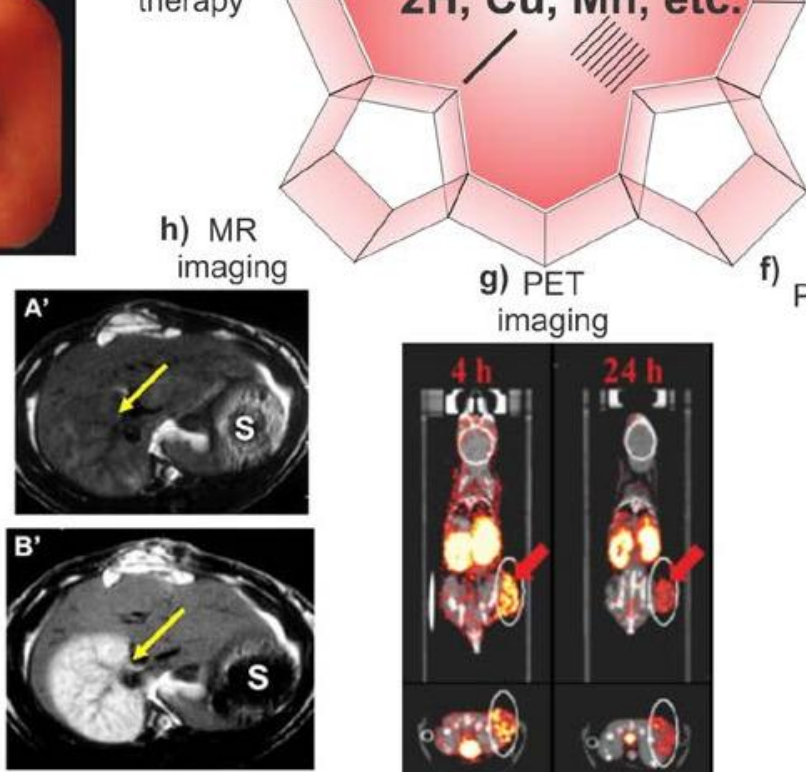

g) PET

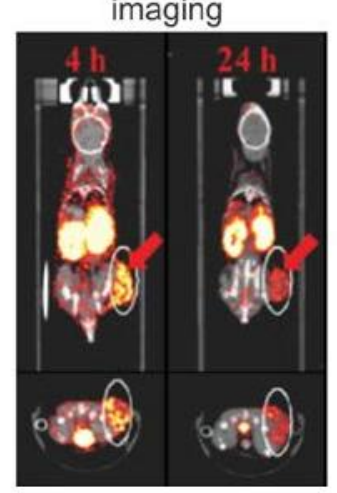

Phot

Photoacoustic imaging

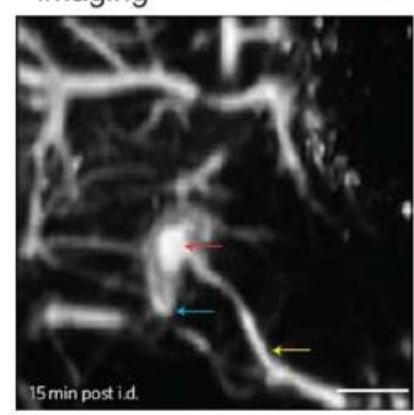

Figure 2: Multimodal theranostic capabilities of exogenous porphyrins. a) Human esophageal cancer successfully treated with PDT [36]. b) Photothermal image of a xenograft bearing mouse injected with porphysomes and then irradiated by laser for I min showing tumor temperature rapidly rising above $60{ }^{\circ} \mathrm{C}$ [44]. c) Radiotherapy: Melanoma imaging of ${ }^{188} \mathrm{Re}-\mathrm{T}_{3,4} \mathrm{CPP}$ in tumor bearing mice. Scintigraphic images were collected at $8 \mathrm{~h} \mathrm{(al)}$ and $24 \mathrm{~h} \mathrm{(a2),} \mathrm{showing} \mathrm{porphyrin} \mathrm{potential} \mathrm{in} \mathrm{radiotherapy} \mathrm{and} \mathrm{imaging} \mathrm{[85].} \mathrm{d)} \mathrm{Near} \mathrm{infrared} \mathrm{fluo-}$ rescence imaging of porphysome activation in a KB xenograft bearing mouse [44]. e) Fluorescence Guided Resection (FGR): the surgical cavity after white light resection of brain tumor in rabbit (top), fluorescence imaging of PpIX showing tumor margins. Additional FGR can improve the accuracy of resection [105]. f) Photoacoustic image of rat lymphatics mapped following intradermal injection of porphysomes in rats [44]. g) PET imaging showing clear delineation between the tumor and other tissues by PET was obtained at $4,24 \mathrm{~h}$ after intravenous injection of a targeted ${ }^{64} \mathrm{Cu}$ porphyrin [ I 16]. h) MR imaging: In the top precontrast TI weighted image, the infarcted right liver lobe (arrow) was barely detected whereas $24 \mathrm{~h}$ after injection of Gadophrin-2 at $0.05 \mathrm{mmol} / \mathrm{kg}$ the infarcted liver lobe was strongly enhanced (bottom) [125]. Reproduced with permission from the publishers of corresponding references. 
Porphyrins and related macrocycles, typically formed with a tetrapyrrole skeleton, can form metalloporphyrin complexes chelated with an incredibly diverse range of metals (e.g. $\mathrm{Li}, \mathrm{Be}, \mathrm{Na}, \mathrm{Mg}, \mathrm{Al}, \mathrm{K}, \mathrm{Ca}$, $\mathrm{Ti}, \mathrm{V}, \mathrm{Cr}, \mathrm{Mn}, \mathrm{Fe}, \mathrm{Co}, \mathrm{Ni}, \mathrm{Cu}, \mathrm{Zn}, \mathrm{Ga}, \mathrm{Ge}, \mathrm{Rb}, \mathrm{Sr}, \mathrm{Ru}$, $\mathrm{Rh}, \mathrm{Pd}, \mathrm{Ag}, \mathrm{Cd}, \mathrm{In}, \mathrm{Sn}, \mathrm{Sb}, \mathrm{Cs}, \mathrm{Ba}, \mathrm{Pt}, \mathrm{Au}, \mathrm{Hg}, \mathrm{Tl}, \mathrm{Pb}$, $\mathrm{Bi}, \mathrm{Th}, \mathrm{Y}, \mathrm{Nd}, \mathrm{Sm}, \mathrm{Eu}, \mathrm{Gd}, \mathrm{Tb}, \mathrm{Dy}, \mathrm{Ho}, \mathrm{Er}, \mathrm{Tm}, \mathrm{Yb}$, and $\mathrm{Lu}$ [ $[89,106-108]$. Just as porphyrins led the way for fluorescence imaging and detection of tumors [90], in 1951, ${ }^{64} \mathrm{Cu}$-porphyrins were first used as positron emission radioisotopes for detection of brain injury and tumor [109]. In this experiment, ${ }^{64} \mathrm{Cu}$ phthalocyanine was synthesized successfully and doses of 100 $\mathrm{mg} / \mathrm{kg}$ were given to rabbits, mice, guinea pigs, cats and dogs, then biodistribution and excretion were studied in rabbits. Although the positron emission tomography (PET) phenomenon has long been known, it has only recently been recognized as a valuable clinical and theranostic imaging modality in the last decades [110,111]. ${ }^{64} \mathrm{Cu}$-porphyrins have been explored as promising probes [112,113] considering their favorable properties including excellent resistance to demetallation [109], minimal toxicity [114], the 12 hour half-life of ${ }^{64} \mathrm{Cu}$, and the pharmacokinetics of porphyrins [115]. Recently, ${ }^{64} \mathrm{Cu}$ was incorporated into targeted peptide consisting of pyropheophorbide- $\alpha$, a peptide linker and folate (PPF). After 4 and $24 \mathrm{~h}$ post-injection, preferred tumor/background ratio and clear delineation of tumor and other tissues was detectable by PET (Fig 2g). In this work, porphyrin accumulation in tumor at $4 \mathrm{~h}$ was larger than that $24 \mathrm{~h}$ post-injection, which could be explained by the active targeting component of the PPF [116]. ${ }^{48} \mathrm{~V}$ labeled pheophorbide has also been examined for PET imaging [117]. In addition to PET, other diagnostic imaging modalities can be used combined such as computed tomography (CT), single photon emission computed tomography (SPECT), ultrasound, and MRI. For instance, PET images offer information on contrast targets with a high sensitivity, while CT and MRI stand out for their high resolutions. Hence, the combination of different imaging strategies (e.g. PET/CT, PET/MRI) compensate for disadvantages of each modality and obtain more reliable and detailed results with high spatial resolution and sensitivity $[118,119]$.

Metalloporphyrins can be also used for enhancing MRI of tumors. MRI can offer information on tissue structure with high sensitivity based on physicochemical and physiological properties [120,121]. However, MRI can have difficulty in distinguishing between neoplastic and normal tissues [122]. Paramagnetic metals can be used as contrast agents that decrease these relaxation times, including the use of metal-chelated porphyrins $[123,124]$. Paramagnetic metals (e.g. $\mathrm{Mn}^{2+}, \mathrm{Gd}^{3+}$ ) are chelated in metalloporphyrins and used as contrast agents which can cause a detectable relaxation in the surrounding water [125]. In 1987, a water soluble metalloporphyrin, manganese (III) tetra-(4-sulfanatophenyl) porphyrin, Mn (III) $\mathrm{TPPS}_{4}$ was investigated as a contrast agent for MRI. Effective proton T1 and T2 relaxations induced by $\mathrm{Mn}(\mathrm{III}) \mathrm{TPPS}_{4}$ were obtained and good MRI enhancement using Mn(III)TPPS was observed in carcinomas, fibrosarcomas and lymphomas [126]. Subsequently, metalloporphyrins of manganese tetrasodium-meso-tetra (4-sulfonatophenyl)-porphine (MnTPPS), manganese meso-tetra-4-pyridylporphine and gadolinium meso-tetra-4-pyridylporphine have been used as tumor specific MR imaging contrast agents in animal models [127]. Paramagnetic metalloporphyrins show good chelate stability, low toxicity and high relaxivities. $\mathrm{Gd}^{3+}$ has more unpaired electron spins and is more paramagnetic than $\mathrm{Mn}^{2+}$; Gd-chelated porphyrins such as Gadophrin-2 (bis-Gd-DTPA-mesoporphyrin), Gadophrin-3 (a copper inserted at the core to improve stability and safety), and texaphyrins have been explored as MRI contrast agents [128-130]. MRI enhancement in necrotic tissue using Gadophrin-2 is clearly shown in Fig $\mathbf{2 h}$. Compared to precontrast $\mathrm{T}_{1}$-weighted MRI, where an infarcted right liver lobe was almost undetectable, 24 hours after a $0.05 \mathrm{mmol} / \mathrm{kg}$ Gadophrin injection, the infarcted lobe was clearly demarcated [125]. It is also worth mentioning that while some degree of tumor specific accumulation of porphyrins may be assumed, this is not always the case. For example, two metalloporphyrins, gadolinium mesoporphyrin (Gd-MP) and manganese tetraphenylporphyrin (Mn-TPP) did not prove to preferentially accumulate in viable tumors tissue of hepatomas [131].

\section{Looking forward}

Porphyrins have great potential to further advance the development of imaging and therapeutic approaches. Endogenous porphyrins will continue to prove their utility as improvements in instrumentation permit higher spatial and temporal resolution for techniques such as fMRI and photoacoustic imaging. Exogenous porphyrins have seen intensive activity in recent decades, resulting in many clinical approvals (e.g. Photofrin, Photolon, Visudyne, Foscan). Some novel porphyrins may continue to take on altered forms that enhance functionality, such as the development of photosensitizers with long wavelength absorptions to increase the penetration depth of light $[36,132]$. Another strategy is the development of activatable photosensitizers to achieve local activation 
and minimize damage to adjacent tissues for PDT [38,133-135]. New porphyrin nanocarriers have been explored, including polymers, micelles, dendrimers, liposomes, along with targeting strategies to better deliver the cargo $[136,137]$.

Polymers are good carriers for porphyrin or phthalocyanine delivery. For instance, tetrakis (meso-hydroxyphenyl) porphrin (mTHPP) was formulated into polymeric micelles made of poly-(ethylene glycol)-co-poy (D, L-Lactic acid) (PEG-PLA) via a simple solvent evaporation method resulting in high loading efficiency (85\%) and desirable micelle size $(\sim 30 \mathrm{~nm})$ [138]. Dendrimers have gained much attention in biomedical applications [139]. Dendritic porphyrins (consisting of a focal porphyrin surrounded by poly benzyl ether dendrons) have been created and demonstrated to selectively accumulate in choroidal neovascularization (CNV) lesions [140]. Liposomes are another commonly explored material for porphyrin delivery [141]. One example is Visudyne, a health regulatory agency approved liposomal formulation of veteporfin [71]. Dipalmitoylphosphatidylcholine (DPPC) liposomes have been used to encapsulate Photofrin in order to enhance photodynamic effect on tumors [142]. While the enhanced permeability and retention effect enables nanoparticles to accumulate in tumor passively, active targeting strategy studies have also attracted much attention to improve specificity. Various targeting agents, showing affinity for a marker that is overexpressed on tumor cells, have been explored for targeting porphyrins, such as antibodies, aptamers, folate, growth factors, transferrin, and lipoproteins [143-147]. Additionally, it is worth mentioning that some new carriers with triggered release mechanisms also hold potential for controlled porphyrin delivery, based on changes in temperature, $\mathrm{pH}$, or light, leading to the carrier breakdown and local drug release [141,148-150]. There are also new experimental emerging areas that feature quite different approaches to porphyrin theranostics. Among them, the porphysome is a recent discovery of an organic nanoparticle formed by the conjugation of porphyrin to a phospholipid [44]. These nanovesicles exhibited large and tunable extinction coefficients and other unique nanoscale biophotonic properties for multimodal therapeutic applications. Porphysomes are also one of the first nanoparticles exhibiting enzymatic biodegradation in vivo [151].

In summary, porphyrins have existed universally since prehistoric times and have contributed, have evolved in step with life as we know it for billions of years, and continue to be prominent in biological, chemical and medical fields. Porphyrins facilitate optical and magnetic detection in the red heme in blood, serving as a natural and excellent theranostic agent. Exogenous porphyrins have also played indispensable and defining roles in modern theranostics, with new agents enabling multimodal imaging and multimodal therapy. With concerted research efforts, porphyrins will continue to add new chapters to their theranostic legacy into the coming decades and beyond.

\section{Acknowledgement}

This article was made possible by University at Buffalo startup funding.

\section{Competing Interests}

The authors have declared that no competing interest exists.

\section{References}

1. Meinschein WG, Barghoorn ES, Schopf JW. Biological remnants in a precambrian sediment. Science 1964;145:262-3.

2. Hodgson GW, Peterson E, Kvenvold KA, Bunnenbe E, Halpern B, Ponnampe C. Search for prophyrins in lunar dust. Science 1970;167:763-5.

3. Barghoorn ES. The oldest fossils. Sci Amer 1971;224:30-42.

4. Canham GWR. Porphyrins and evolutions. Canadian Chemical Education 1972;8:5-6.

5. Zuckerkandl E. The evolution of hemoglobin. Sci Amer 1965;212:110-8.

6. Fermi G, Perutz MF, Shaanan B, Fourme R. The crystal structure of human deoxyhaemoglobin at $1.74 \mathrm{~A}$ resolution. I Mol Biol 1984;175:159-74.

7. Schweitzer, MH, Wittmeyer, JL, Horner, JR, Toporski, JK. Soft-tissue vessels and cellular preservation in tyrannosaurus rex. Science 2005;307:1952-5.

8. Pierigè F, Serafini S, Rossi L, Magnani M. Cell-based drug delivery. Adv Drug Delivery Rev 2008;60:286-95.

9. Beutler E, Lichtman MA, Coller B.S., Kipps T.J. Examination of the blood. In: Williams' Hematology; 5th ed. New York: McGraw-Hill, Inc. 1995.

10. Hunefeld, F. L. Die chemismus in der thierischen organization. Brockhaus: Leipzig, 1840

11. Perutz MF, Rossmann MG, Cullis AF, Muirhead H, Will G, North ACT. Structure of hemoglobin: A three-dimensional fourier synthesis at 5.5- $\AA$. resolution, obtained by X-ray analysis. Nature 1960;185:416-22.

12. Birren F. Color psychology and color therapy; a factual study of the influence of color on human life. New Hyde Park, NY: University Books, 1961.

13. Birren, Faber. Color \& human response : aspects of light and color bearing on the reactions of living things and the welfare of human beings. New York: Van Nostrand Reinhold Co., 1978.

14. Kelkar SS, Reineke TM. Theranostics: Combining Imaging and Therapy. Bioconjugate Chem 2011;22:1879-903.

15. Vannotti A. Porphyrins: their biological and chemical importance. London: Hilger \& Watts, 1954.

16. Purcell EM, Torrey HC, Pound RV. Resonance absorption by nuclear magnetic moments in a solid. Phys Rev 1946;69:37-8.

17. Buxton RB. Introduction to Functional Magnetic Resonance Imaging: Principles and Techniques; 1st ed. Cambridge, UK: Cambridge University Press, 2002.

18. Belliveau J, Kennedy D, Mckinstry R, Buchbinder B, Weisskoff R, Cohen M, Vevea J, Brady T, Rosen B. Functional mapping of the human visual-cortex by magnetic resonance imaging. Science 1991;254:716-9.

19. Kwong KK, Belliveau JW, Chesler DA, Goldberg IE, Weisskoff RM, Poncelet BP, Kennedy DN, Hoppel BE, Cohen MS, Turner R. Dynamic magnetic resonance imaging of human brain activity during primary sensory stimulation. Proc Natl Acad Sci U S A 1992;89:5675-9.

20. Ogawa S, Tank DW, Menon R, Ellermann JM, Kim SG, Merkle H, Ugurbil K. Intrinsic signal changes accompanying sensory stimulation: functional brain mapping with magnetic resonance imaging. Proc Natl Acad Sci U S A 1992;89:5951-5. 
21. Ogawa S, Lee T-M, Nayak AS, Glynn P. Oxygenation-sensitive contrast in magnetic resonance image of rodent brain at high magnetic fields. Magn Reson Med 1990;14:68-78.

22. Bick AS, Goelman G, Frost R. Hebrew brain vs. English brain: language modulates the way it is processed. J Cognitive Neurosci 2010;23:2280-90.

23. Kim C, Favazza C, Wang LV. In vivo photoacoustic tomography of chemicals: high-resolution functional and molecular optical imaging at new depths. Chem Rev 2010;110:2756-82.

24. Xu M, Wang LV. Photoacoustic imaging in biomedicine. Rev Sci Instrum 2006;77:041101.

25. Wang LV. Prospects of photoacoustic tomography. Med Phys 2008;35:5758-67.

26. Wang X, Pang Y, Ku G, Xie X, Stoica G, Wang LV. Noninvasive laser-induced photoacoustic tomography for structural and functional in vivo imaging of the brain. Nature Biotechnology 2003;21:803-6.

27. Ermilov SA, Khamapirad T, Conjusteau A, Leonard MH, Lacewell R, Mehta K, Miller T, Oraevsky AA. Laser optoacoustic imaging system for detection of breast cancer. I Biomed Opt 2009;14:024007.

28. Zhang HF, Maslov K, Stoica G, Wang LV. Functional photoacoustic microscopy for high-resolution and noninvasive in vivo imaging. Nature Biotechnology 2006;24:848-51.

29. Li C, Wang LV. Photoacoustic tomography and sensing in biomedicine. Phys Med Biol 2009;54:R59-R97.

30. Dougherty TJ, Gomer CJ, Henderson BW, Jori G, Kessel D, Korbelik M, Moan J, Peng Q. Photodynamic therapy. J Natl Cancer Inst 1998:90:889-905

31. Oleinick NL, Morris RL, Belichenko I. The role of apoptosis in response to photodynamic therapy: what, where, why, and how. Photochem Photobiol Sci 2002;1:1-21.

32. Kessel D. Delivery of photosensitizing agents. Adv Drug Deliv Rev 2004;56:7-8.

33. Agostinis P, Berg K, Cengel KA, Foster TH, Girotti AW, Gollnick SO, Hahn SM, Hamblin MR, Juzeniene A, Kessel D, Korbelik M, Moan J, et al. Photodynamic therapy of cancer: An update. CA-Cancer J Clin 2011;61:250-81.

34. O'Connor AE, Gallagher WM, Byrne AT. Porphyrin and nonporphyrin photosensitizers in oncology: preclinical and clinical advances in photodynamic therapy. Photochem Photobiol 2009;85:1053-74.

35. Brown SB, Brown EA, Walker I. The present and future role of photodynamic therapy in cancer treatment. Lancet Oncol 2004;5:497-508.

36. Pandey RK, Goswami LN, Chen Y, Gryshuk A, Missert JR, Oseroff A, Dougherty TJ. Nature: A rich source for developing multifunctional agents. Tumor-imaging and photodynamic therapy. Laser Surg Med 2006;38:445-67.

37. Kadish KM, Smith KM, Guilard R. The porphyrin handbook. San Diego : Academic Press, 2000.

38. Lovell JF, Liu TWB, Chen J, Zheng G. Activatable photosensitizers for imaging and therapy. Chem Rev 2010;110:2839-57.

39. Moan J. On the diffusion length of singlet oxygen in cells and tissues. $J$ Photochem Photobiol B 1990;6:343-7.

40. Soncin M, Busetti A, Fusi F, Jori G, Rodgers MAJ. Irradiation of amelanotic melanoma cells with $532 \mathrm{~nm}$ high peak power pulsed laser radiation in the presence of the photothermal sensitizer $\mathrm{Cu}$ (II)-hematoporphyrin: a new approach to cell photoinactivation. Photochem Photobiol 1999;69:708-12.

41. Busetti A, Soncin M, Reddi E, Rodgers MAJ, Kenney ME, Jori G. Photothermal sensitization of amelanotic melanoma cells by Ni(II)-octabutoxy-naphthalocyanine. $J$ Photochem Photobiol B 1999;53:103-9.

42. Camerin M, Rello S, Villanueva A, Ping X, Kenney ME, Rodgers MAJ, Jori G. Photothermal sensitisation as a novel therapeutic approach for tumours: Studies at the cellular and animal level. Eur J Cancer 2005;41:1203-12.

43. Camerin M, Rodgers MAJ, Kenney ME, Jori G. Photothermal sensitisation: evidence for the lack of oxygen effect on the photosensitising activity. Photochem Photobiol Sci 2005;4:251-3.

44. Lovell JF, Jin CS, Huynh E, Jin H, Kim C, Rubinstein JL, Chan WCW, Cao W, Wang LV, Zheng G. Porphysome nanovesicles generated by porphyrin bilayers for use as multimodal biophotonic contrast agents. $\mathrm{Na}$ ture Materials 2011;10:324-32.

45. Lal S, Clare SE, Halas NJ. Nanoshell-enabled photothermal cancer therapy: impending clinical impact. Acc Chem Res 2008;41:1842-51.

46. Chen WR, Adams RL, Bartels KE, Nordquist RE. Chromophore-enhanced in vivo tumor cell destruction using an 808-nm diode laser. Cancer Lett 1995;94:125-31.

47. Isak SJ, Eyring EM, Spikes JD, Meekins PA. Direct blue dye solutions: photo properties. J Photochem Photobiol A 2000;134:77-85.
48. Mazzaglia A, Trapani M, Micali N, Scolaro LM, Parisi T, Sciortino MT. Investigation of amphiphilic cyclodextrins encapsulating gold colloids and porphyrins for combined photodynamic and photothermal therapy on tumor HeLa cells. J Biotechnol 2010;150:S192-S192.

49. Tappeiner HV, Jesionek A. Therapeutische versuche mit fluorescierenden stoffen. Munchener Medizinische Wochenschrift 1903;47:2042-4.

50. Jesionek A, Tappeiner HV. Zur behandlung der hautcarcinome mit fluorescierenden stoffen. Archiv fur klinische Medizin 1905;82:223.

51. Moan J, Peng Q. An outline of the hundred-year history of PDT. Anticancer Res 2003;23:3591-600.

52. Tappeiner HV. Ueber die Wirkung fluorescierenden stoffe auf Infusionrien nach versuchen Von O. Raab. Munchener Medizinische Wochenschrift $1900 ; 47: 5$

53. Raab O. Ueber die wirkung fluorescierenden stoffe auf infusorien. Zeitschrift fur Biologie 1900;39:524-46.

54. Tappeiner HV, Jodlbauer A. Uber die wirkung der photodynamischen (fluorescierenden) stoffe auf protozoen und enzyme. Deutsches Archiv fur klinische Medizin 1904;80:327-487.

55. Tappeiner HV, Jodlbauer A. Die sensibilisierende wirkung fluorescierender substanzer. untersuchungen uber die photodynamische erscheinung. FCW Vogel Leizig, 1907.

56. Scherer, H. Chemisch-physiologische untersuchungen. Annalen der Chemie und Pharmazie 1841:40:1-64.

57. Ackroyd R, Kelty C, Brown N, Reed M. The history of photodetection and photodynamic therapy. Photochem Photobiol 2001;74:656-69.

58. Thudichum JL. Tenth report of the medical office of the privy council. London: HM Stationary Office, 1867.

59. Hausmann, W. Die sensibilisierende wirkung des hematoporphyrins. Biochemische Zeitschrift 1911;30:276-316.

60. Meyer-Betz, F. Untersuchungen uder die Biologische (photodynamische) wirkung des hamatoporphyrins und anderer derivative des blu- und galenfarbstoffs. Deutsches Archiv fur klinische Medizin 1913;112:476-503.

61. Winkelman J. The distribution of Tetraphenylporphinesulfonate in the tumor-bearing rat. Cancer Res 1962;22:589-96.

62. Daniell, M. D, Hill JS. A history of photodynamic therapy. Aust N Z J Surg 1991;61:340-8.

63. Diamond I, Jaenicke R, Wilson CB, Mcdonagh AF, Nielsen S, Granelli SG. Photodynamic therapy of malignant tumors. Lancet 1972;2:1175-7.

64. Dougherty TJ, Gb Grindey, Fiel R, Weishaupt KR, Boyle DG. Photoradiation therapy. II. Cure of animal tumors with hematoporphyrin and light. J Natl Cancer Inst 1975;55:115-21.

65. Kelly, JF, Snell, ME, Berenbaum,M. Photodynamic destruction of human bladder carcinomas. Brit J Cancer 1975;31:237-44.

66. Benhur E, Rosenthal I. Photosensitized inactivation of Chinese hamster cells by phthalocyanines. Photochem Photobiol 1985;42:129-33.

67. Phillips D. Chemical mechanisms in photodynamic therapy with phthalocyanines. Prog React Kinet 1997;22:175-300.

68. Wohrle D, Hirth A, Bogdahn-Rai T, Schnurpfeil G, Shopova M. Photodynamic therapy of cancer: second and third generations of photosensitizers. Russ Chem Bull 1998;47:807-16.

69. Sharman WM, Allen CM, Van Lier JE. Photodynamic therapeutics: basic principles and clinical applications. Drug Discov Today 1999;4:507-17.

70. Trachtenberg J, Bogaards A, Weersink RA, Haider MA, Evans A, McCluskey SA, Scherz A, Gertner MR, Yue C, Appu S, Aprikian A, Savard J, et al. Vascular targeted photodynamic therapy with Palladium-bacteriopheophorbide photosensitizer for recurrent prostate cancer following definitive radiation therapy: assessment of safety and treatment response. J Urol 2007;178:1974-9.

71. Schmidt-Erfurth U, Hasan T. Mechanisms of action of photodynamic therapy with verteporfin for the treatment of age-related macular degeneration. Surv Ophthalmol 2000;45:195-214.

72. Bressler NM. Photodynamic therapy of subfoveal choroidal neovascularization in age-related macular degeneration with verteporfin: two-year results of 2 randomized clinical trials-tap report 2. Arch Ophthalmol 2001;119:198-207.

73. Bressler NM, Arnold J, Benchaboune M, Blumenkranz MS, Fish GE, Gragoudas ES, Lewis H, Schmidt-Erfurth U, Slakter JS, Bressler SB, Manos K, Hao Y, et al. Verteporfin therapy of subfoveal choroidal neovascularization in patients with age-related macular degeneration - Additional information regarding baseline lesion composition's impact on vision outcomes-TAP report No. 3. Arch Ophthalmol 2002;120:1443-54.

74. Bressler NM. Verteporfin therapy for subfoveal choroidal neovascularization in age-related macular degeneration - Three-year results of an open-label extension of 2 randomized clinical trials - TAP report No. 5. Arch Ophthalmol 2002;120:1307-14. 
75. Ferris F, Fine S, Hyman L. Age-related macular degeneration and blindness due to neovascular maculopathy. Arch Ophthalmol 1984;102:1640-2.

76. Hamblin MR, Hasan T. Photodynamic therapy: a new antimicrobial approach to infectious disease? Photochem Photobiol Sci 2004;3:436-50.

77. James WD. Acne. N Engl J Med 2005;352:1463-72.

78. Katsambas AD, Stefanaki C, Cunliffe WJ. Guidelines for treating acne. Clin Dermatol 2004;22:439-44.

79. Gold MH. Acne and PDT: new techniques with lasers and light sources. Lasers Med Sci 2007;22:67-72.

80. Ross EV. Optical treatments for acne. Dermatol Ther 2005;18:253-66.

81. Riddle CC, Terrell SN, Menser MB, Aires DJ, Schweiger ES. A review of photodynamic therapy (PDT) for the treatment of acne vulgaris. J Drugs Dermatol 2009;8:1010-9.

82. Hædersdal M, Togsverd-Bo K, Wulf HC. Evidence-based review of lasers, light sources and photodynamic therapy in the treatment of acne vulgaris. J Eur Acad Dermatol 2008;22:267-78.

83. Nair CKK, Parida DK, Nomura T. Radioprotectors in radiotherapy. J Radiat Res 2001;42:21-37.

84. Das T, Chakraborty S, Sarma HD, Banerjee S. A novel [Pd-109] palladium labeled porphyrin for possible use in targeted radiotherapy. Radiochim Acta 2008;96:427-33.

85. Jia $\mathrm{Z}$, Deng $\mathrm{H}, \mathrm{Pu} \mathrm{M}$, Luo $\mathrm{S}$. Rhenium-188 labelled meso-tetrakis[3,4-bis(carboxymethyleneoxy)phenyl] porphyrin for targeted radiotherapy: preliminary biological evaluation in mice. Eur J Nucl Med Mol Imaging 2008;35:734-42.

86. Vaum R, Heindel N, Burns H, Emrich J, Foster N. Synthesis and evaluation of an in-111-labeled porphyrin for lymph-node imaging. J Pharm Sci 1982;71:1223-6.

87. Crone-Escanye MC, Anghileri LJ, Robert J. In vivo distribution of $54 \mathrm{Mn}$-hematoporphyrin derivative in tumor bearing mice. J Nucl Med Allied Sci 1988;32:237-41.

88. Hambright $\mathrm{P}$, Fawwaz R, Valk $\mathrm{P}, \mathrm{McRae} J$, Bearden AJ. The distribution of various water soluble radioactive metalloporphyrins in tumor bearing mice. Bioinorg Chem 1975;5:87-92.

89. Ali H, van Lier JE. Metal complexes as photo- and radiosensitizers. Chem Rev 1999;99:2379-450.

90. Policard A. Etude sur les aspects offerts par des tumeurs experimentales examinees a la lumiere de Wood. C R Soc Biol 1924;91:1423-8.

91. Korbler J. Untersuchung von krebsgewebe im fluoreszenzerregenden licht. Strahlentherapie 1931;41:510-8.

92. Auler H, Banzer G. Untersuchungen uber die rolle der porphyrine bei geschwulstkranken menschen und tieren. Zeitschrift fur Krebsforschung 1942;53:65-8.

93. Figge FHJ, Weiland GS, Manganiello LOJ. Cancer detection and therapy: affinity of neoplastic, embryonic and traumatised tissues for porphyrins and metallo-porphyrins. Proc Soc Exp Biol Med 1948;68:640-1.

94. Manganiello LOJ, Figge FHJ. Cancer detection and therapy 11: Methods of preparation and biological effects of metallo-porphyrins. Bull Sch Med Univ Maryland 1951;36:3-7.

95. Rasmussen TDS, Ward GE, Figge FHJ. Fluorescenceof human lymphatic and cancer tissues following high doses of intravenous hematoporphyrin. Cancer 1955;8:78-81.

96. Leblond F, Davis SC, Valdés PA, Pogue BW. Pre-clinical whole-body fluorescence imaging: Review of instruments, methods and applications. I Photochem Photobiol B 2010;98:77-94.

97. Josefsen LB, Boyle RW. Photodynamic therapy and the development of metal-based photosensitisers. Met Based Drugs 2008;2008:276109.

98. Wilson BC, Patterson MS. The physics, biophysics and technology of photodynamic therapy. Phys Med Biol 2008;53:R61-R109.

99. Blake E, Allen J, Curnow A. An In vitro comparison of the effects of the iron-chelating agents, CP94 and dexrazoxane, on protoporphyrin IX accumulation for photodynamic therapy and/or fluorescence guided resection. Photochem and Photobiol 2011:87:1419-26.

100. Stummer W, Novotny A, Stepp H, Goetz C, Bise K, Reulen HJ. Fluorescence-guided resection of glioblastoma multiforme by using 5-aminolevulinic acid-induced porphyrins: a prospective study in 52 consecutive patients. J Neurosurg 2000;93:1003-13.

101. Stummer W, Pichlmeier U, Meinel T, Wiestler OD, Zanella F, Reulen H-J. Fluorescence-guided surgery with 5-aminolevulinic acid for resection of malignant glioma: a randomised controlled multicentre phase III trial. Lancet Oncol 2006;7:392-401.

102. Pichlmeier U, Bink A, Schackert G, Stummer W. Resection and survival in glioblastoma multiforme: An RTOG recursive partitioning analysis of ALA study patients. Neuro Oncol 2008;10:1025-34.
103. Valdés PA, Fan X, Ji S, Harris BT, Paulsen KD, Roberts DW. Estimation of brain deformation for volumetric image updating in protoporphyrin IX fluorescence-guided resection. Stereotact Funct Neurosurg 2010;88:1-10.

104. Valdés PA, Leblond F, Kim A, Harris BT, Wilson BC, Fan X, Tosteson TD, Hartov A, Ji S, Erkmen K, Simmons NE, Paulsen KD, et al. Quantitative fluorescence in intracranial tumor: implications for ALA-induced PpIX as an intraoperative biomarker. J Neurosurg 2011;115:11-7.

105. Bogaards A, Varma A, Collens SP, Lin A, Giles A, Yang VXD, Bilbao JM, Lilge LD, Muller PJ, Wilson BC. Increased brain tumor resection using fluorescence image guidance in a preclinical model. Laser Surg Med 2004;35:181-90.

106. Biesaga M, Pyrzyńska K, Trojanowicz M. Porphyrins in analytical chemistry. A review. Talanta 2000;51:209-24.

107. Beletskaya I, Tyurin VS, Tsivadze AY, Guilard R, Stern C. Supramolecular chemistry of metalloporphyrins. Chem Rev 2009;109:1659-713.

108. Hambright P. The coordination chemistry of metalloporphyrins. Coord Chem Rev 1971;6:247-68.

109. Wrenn FR, Myron L. Good, Handler P. The use of positron-emitting radioisotopes for the localization of brain tumors. Science 1951;113:525-7.

110. Sörensen J. How does the patient benefit from clinical PET? Theranostics 2012;2:427-36.

111. Yaghoubi SS. Positron emission tomography reporter genes and reporter probes: gene and cell therapy applications. Theranostics 2012;2:374-91.

112. Wilson B C, Firnau G, Jeeves WP, Brwon KL, Burns-McCormick DM. Chromatographic analysis and tissue distribution of radiocopper-lablled haematoporphyrin derivatives. Lasers Med Sci 1998;3:71-80.

113. Soucy-Faulkner A et al. Copper-64 labelled sulfophthalocyanines for positron emission tomography (PET) imaging in tumor-bearing rats. I Porphyrins Phthalocyanines 2008;12:49-53.

114. Bases R, Brodie SS, Rubenfeld S. Attempts at tumor localization using $\mathrm{Cu}$ 64-labeled copper porphyrins. Cancer 1958;11:259-63.

115. Firnau G, Wilson B C, Jeeves WP. 64Cu labelling of hematoporphyrin derivative for non-invasive in-vivo measurements of tumour uptake. Prog Clin Biol Res 1984;170:629-36.

116. Shi J, et al. Transforming a targeted porphyrin theranostic agent into a PET imaging probe for cancer. Theranostics 2011;1:363-70.

117. Iwai K, Kimura S, Ido $T$, Iwata R. Tumor uptake of [48V]Vanadyl-chlorine e6 $\mathrm{Na}$ as a tumor-imaging agent in tumor-bearing mice. Nucl Med Biol 1990;17:775-80.

118. Lee D-E, Koo H, Sun I-C, Ryu JH, Kim K, Kwon IC. Multifunctional nanoparticles for multimodal imaging and theragnosis. Chem Soc Rev 2012;41:2656-72.

119. Louie A. Multimodality imaging probes: design and challenges. Chem Rev 2010;110:3146-95.

120. Morgan CJ, Hendee WR. Introduction to magnetic resonance imaging. Denver: Multi-Media Publishing, 1984.

121. Braunschweiger PG, Schiffer LM, Furmanski P. 1H-NMR relaxation times and water compartmentalization in experimental tumor models. Magn Reson Imaging 1986;4:335-42.

122. Bottomley PA, Hardy CJ, Argersinger RE, Allen-Moore G. A review of $1 \mathrm{H}$ nuclear magnetic resonance relaxation in pathology: Are T1 and T2 diagnostic? Med Phys 1987;14:1-37.

123. Manabe Y, Longley C, Furmanski P. High-level conjugation of chelating agents onto immunoglobulins: use of an intermediary poly(L-lysine)-diethylenetriaminepentaacetic acid carrier. Biochim Biophys Acta 1986;883:460-7.

124. Chen C, Cohen JS, Myers CE, Sohn M. Paramagnetic metalloporphyrins as potential contrast agents in NMR imaging. FEBS Lett 1984;168:70-4.

125. Ni Y. Metalloporphyrins and functional analogues as MRI contrast agents. Curr Med Imag Rev 2008;4:96-112.

126. Ogan M, Revel D, Brasch R. Metalloporphyrin contrast enhancement of tumors in magnetic-resonance-imaging - a study of human carcinoma, lymphoma, and fibrosarcoma in mice. Invest Radiol 1987;22:822-8.

127. Furmanski P, Longley C. Metalloporphyrin enhancement of magnetic resonance imaging of human tumor xenografts in nude mice. Cancer Res 1988;48:4604-10.

128. Young SW, Qing F, Harriman A, Sessler JL, Dow WC, Mody TD, Hemmi GW, Hao YP, Miller RA. Gadolinium(III) texaphyrin: A tumor selective radiation sensitizer that is detectable by MRI. Proc Natl Acad Sci U S A 1996;93:6610-5.

129. Ni Y, Pislaru C, Bosmans H, Pislaru S, Miao Y, Bogaert J, Dymarkowski S, Yu J, Semmler W, Van de Werf F, Baert AL, Marchal G. Intracoronary delivery of Gd-DTPA and Gadophrin-2 for determination of myocardial viability with MR imaging. Eur Radiol 2001;11:876-83.

130. Barkhausen J, Ebert W, Debatin JF, Weinmann HJ. Imaging of myocardial infarction: Comparison of magnevist and gadophrin-3 in rabbits. $J$ Am Coll Cardiol 2002;39:1392-8. 
131. Ni Y, Marchal G, Jie Y, Lukito G, Petré C, Wevers M, Baert AL, Ebert W, Hilger C-S, Maier F-K, Semmler W. Localization of metalloporphyrin-induced "specific" enhancement in experimental liver tumors: Comparison of magnetic resonance imaging, microangiographic, and histologic findings. Acad Radiol 1995;2:687-99.

132. Wilson BC, Jeeves WP, Lowe DM, Adam G. Light propagation in animal tissues in the wavelength range 375-825 nanometers. Prog Clin Biol Res 1984;170:115-32.

133. Zheng G, Chen J, Stefflova K, Jarvi M, Li H, Wilson BC. Photodynamic molecular beacon as an activatable photosensitizer based on protease-controlled singlet oxygen quenching and activation. Proc Natl Acad Sci U S A 2007;104:8989-94.

134. Zheng G, Graham A, Shibata M, Missert JR, Oseroff AR, Dougherty TJ, Pandey RK. Synthesis of $\beta$-galactose-conjugated chlorins derived by enyne metathesis as galectin-specific photosensitizers for photodynamic therapy. J Org Chem 2001;66:8709-16.

135. Lovell JF, Chan MW, Qi Q, Chen J, Zheng G. Porphyrin FRET acceptors for apoptosis induction and monitoring. J Am Chem Soc 2011;133:18580-2.

136. Peer D, Karp JM, Hong S, Farokhzad OC, Margalit R, Langer R. Nanocarriers as an emerging platform for cancer therapy. Nature Nanotechnology 2007;2:751-60.

137. Ali I, et al. Advances in nano drugs for cancer chemotherapy. Curr Cancer Drug Targets 2011;11:135-46.

138. Cohen EM, Ding H, Kessinger CW, Khemtong C, Gao J, Sumer BD. Polymeric micelle nanoparticles for photodynamic treatment of head and neck cancer cells. Otolaryngol Head Neck Surg 2010;143:109-15.

139. Nishiyama N, Jang W-D, Kataoka K. Supramolecular nanocarriers integrated with dendrimers encapsulating photosensitizers for effective photodynamic therapy and photochemical gene delivery. New J Chem 2007;31:1074-82.

140. Ideta R, Tasaka F, Jang W-D, Nishiyama N, Zhang G-D, Harada A, Yanagi Y, Tamaki Y, Aida T, Kataoka K. Nanotechnology-based photodynamic therapy for neovascular disease using a supramolecular nanocarrier loaded with a dendritic photosensitizer. Nano Lett 2005;5:2426-31.

141. Derycke ASL, de Witte PAM. Liposomes for photodynamic therapy. Adv Drug Delivery Rev 2004;56:17-30.

142. Jiang F, Lilge L, Grenier J, Li Y, Wilson MD, Chopp M. Photodynamic therapy of U87 human glioma in nude rat using liposome-delivered photofrin. Laser Surg Med 1998;22:74-80.

143. Derycke ASL, Kamuhabwa A, Gijsens A, Roskams T, De Vos D, Kasran A, Huwyler J, Missiaen L, de Witte P a. M. Transferrin-conjugated liposome targeting of photosensitizer AlPcS4 to rat bladder carcinoma cells. J Natl Cancer Inst 2004;96:1620-30.

144. Gupta S, Chaudhury N, Muralidhar K, Dwarakanath B, Mishra A, Jain V. In vitro and in vivo targeted delivery of photosensitizers to the tumor cells for enhanced photodynamic effects. J Can Res Ther 2011;7:314-24.

145. Gijsens A, Missiaen L, Merlevede W, de Witte P. Epidermal growth factor-mediated targeting of chlorin e6 selectively potentiates its photodynamic activity. Cancer Res 2000;60:2197-202.

146. Morgan J, Lottman H, Abbou C, Chopin D. Comparison of direct and liposomal antibody conjugates of sulfonated Aluminum phthalocyanines for selective photoimmunotherapy of human bladder-carcinoma. Photochem Photobiol 1994;60:486-96.

147. Shieh Y-A, Yang S-J, Wei M-F, Shieh M-J. Aptamer-based tumor-targeted drug delivery for photodynamic therapy. ACS Nano 2010;4:1433-42.

148. Ricchelli F, Gobbo S, Jori G, Salet C, Moreno G. Temperature-induced changes in fluorescence properties as a probe of porphyrin microenvironment in lipid-membranes 2 . The partition of hematoporphyrin and protoporphyrin in mitochondria. Eur J Biochem 1995;233:165-70.

149. Anderson VC, Thompson DH. Triggered release of hydrophilic agents from plasmalogen liposomes using visible light or acid. Biochim Biophys Acta 1992;1109:33-42.

150. Lovell JF, Jin H, Ng KK, Zheng G. Programmed nanoparticle aggregation using molecular beacons. Angew Chem Int Ed 2010;49:7917-9.

151. Lovell JF, Jin CS, Huynh E, MacDonald TD, Cao W, Zheng G. Enzymatic regioselection for the synthesis and biodegradation of porphysome nanovesicles. Angew Chem Int Ed 2012;51:2429-33. 